\title{
Polska edukacja domowa jako mise en abyme między kondyciq ludzkq a społecznymi konstrukcjami oświatowymi
}

\author{
The Polish Home Education as a "Mise en Abyme" \\ Between the Human Condition \\ and Social Constructs of Education
}

\begin{abstract}
ABSTRAKT
Edukacja domowa, rozumiana jako społeczna forma organizacji edukowania dzieci i młodzieży, której koordynatorami sq rodzice, a nie zawodowi oświatowcy pracujący w szkole, staje się, nie tylko w Polsce, głównq alternatywq wobec państwowej oferty oświatowej. Nic zatem dziwnego, że właśnie w okresie znacznego jej ilościowego poszerzania się towarzysza jej funkcjonowaniu szczególnie ożywione dyskusje. Przy wykorzystaniu krytycznoliterackiej i - szerzej - krytycznoartystycznej kategorii mise en abyme autor chciałby wykazać „rozpięcie” edukacji domowej między powszednimi, ateoretycznymi rodzicielskimi wglądami w kondycję dziecka, a ściślej w antropologiczne warunki edukacji z ich osobniczymi konkretyzacjami, a politycznie motywowanymi przesqqdzeniami co do tego, kim młody człowiek jest, a kim winien się stać wskutek regularnej, a więc szkolnej edukacji. Będzie to perspektywa układu zwierciadeł, z ich walorami i defektami, które to zwierciadła
\end{abstract}


tyleż adekwatnie oddajq, co politycznie zniekształcajq człowieczeństwo w ramach pojedynczych edukacyjnych zdarzeń i ich ciqgów. Tak postrzegana, aktualna kondycja polskiej edukacji domowej wydaje się trudna, acz dysponuje sporym potencjałem optymalizacyinym.

\section{ABSTRACT}

Home education, treated as a social organizational form of instructing children and youth, where the coordinators are the parents instead of professional teachers working at a school, emerges as the main alternative to the governmental offer in the field of education, and not just in Poland. It is no surprise then that in the period of important quantitative expansion, home education is being discussed fervently. By using a literary and artistic criticism notion of mise en abyme, the author would like to demonstrate the tensed span of home education between the everyday, atheoretical parental insights into their child's condition, and, more precisely, into the anthropological conditions of education with a personal substantiation, and politically motivated conclusions as to who a young person is, and - as a result of a regular, school education - who he or she shall become. It will be a perspective of a set of mirrors, with all their advantages and deficiencies, which adequately represents, or politically deforms humanity within single educational events or their continuations. In this way, the present condition of Polish education seems to be relatively hard, having at its disposal considerable optimizing potential as well.

\section{Zamiast wstępu - kategoria mise en abyme w kulturze}

Proszę pozwolić, iż najpierw pojawi się wytłumaczenie kaprysu zastosowania $\mathrm{w}$ niniejszej prezentacji na temat edukacji domowej, w charakterze metafory, egzotycznej, pierwotnie francuskiej, kategorii krytyki artystycznej, jaką jest mise en abyme.

Mise en abyme to każdorazowo jakaś odmiana rekurencji - samopowtarzalności, samozwrotności albo też regresu do nieskończoności - która, poza matematycznymi idealizacjami, w prawdziwym życiu jest zwyczajnie podatna na różnorakie deformacje ${ }^{1}$.

1 Zob. np. L. Dällenbach, Le récit spéculaire. Essai sur la mise en abyme, Paris 1977. 
Jak się wydaje, kategoria ta i jej wizualne reprezentacje dysponują sporym, potąd jeszcze nie „zagospodarowanym” potencjałem pedagogicznym (dla teorii nauk o edukacji) i edukacyjnym (dla takiejże praktyki). Zobrazujmy literalnie, a raczej figuratywnie, trzy względnie „czyste” (tj. występujące bez deformacji, obrotów i przesunięć) sytuacje typu mise en abyme. Pierwszą z tych sytuacji jest tzw. „efekt Droste'a", wywodzący swe miano od nazwy holenderskiej firmy produkującej kakao, a dostrzegalny w opakowaniu jej produktu z 1904 roku, z charakterystycznym, zgrabnie, bez mechaniczności zmultiplikowanym wizerunkiem pielęgniarki.

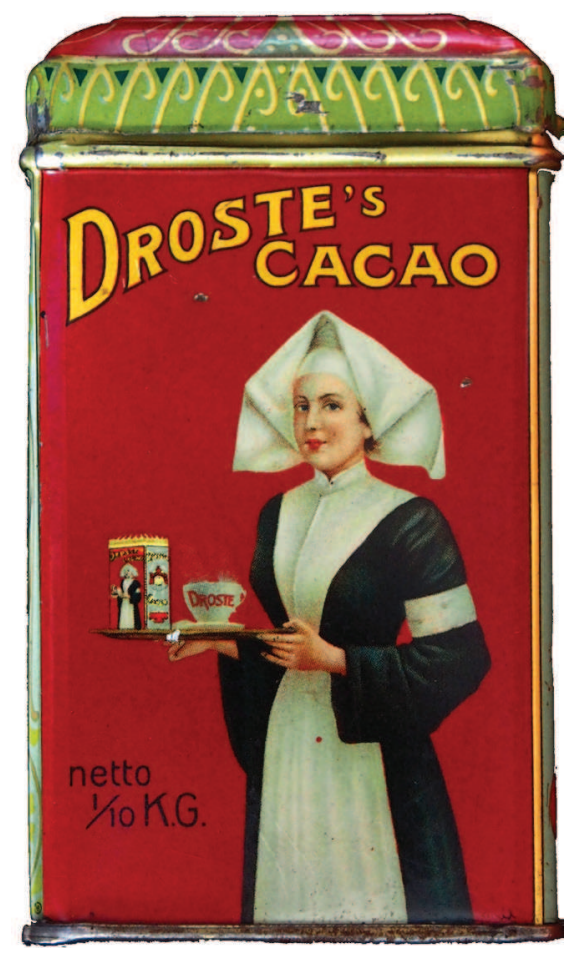

\section{Ilustracja l.}

Pudetko kakao firmy Droste (ok. 1920 r.),

$<$ https://en.wikipedia.org/wiki/Droste_effect>.

Mimo że mogłoby się wydawać, iż efekt ten ma stosunkowo późną metrykę, identyczną grę wizualnymi formami - tj. lokowanie miniatury pewnego obrazu w tymże samym obrazie - to jednak artyści plastycy uprawiali ją już od dawna. Za jeden z pierwszych, 
najbardziej znanych tego typu artefaktów ${ }^{2}$ uważa się, liczące sobie okrągłe 700 lat, malowidło na predelli, tzw. Tryptyk Stefaneschiego, ufundowany dla ołtarza głównego „starej”, średniowiecznej Bazyliki św. Piotra w Rzymie (obecnie będący w zbiorach Pinakoteki Watykańskiej), a namalowany przez samego Giotta di Bondone. $\mathrm{Na}$ środkowym segmencie tego tryptyku kardynał Jakub Stefaneschi, fundator dzieła, prezentuje św. Piotrowi miniaturę... całego tryptyku.

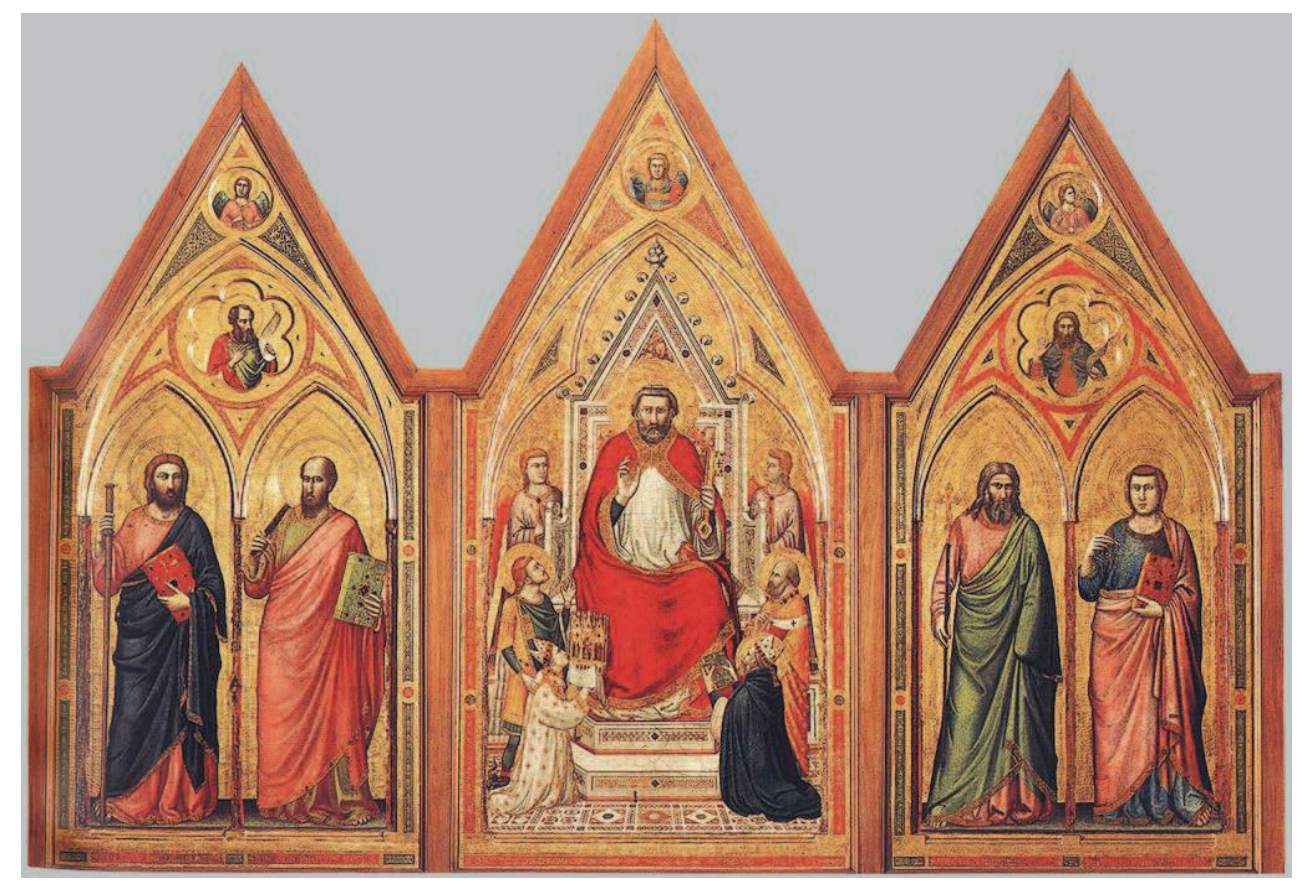

llustracja 2.

Giotto di Bondone (ok. 1320 r.), Tryptyk Stefaneschiego, Muzeum Watykańskie, <http://www.museivaticani.va/content/museivaticani/en/collezioni/musei/la-pinacoteca/ sala-ii---secolo-xiii-xv/giotto-di-bondone-e-aiuti--trittico-stefaneschi.html>.

2 Zob. na ten temat zbiór artykułów zawartych w: <https://web.archive.org/ web/20131102033517/; http://www.courtauld.ac.uk/researchforum/projects/ medievalarttheory/documents/Mise-en-abyme.pdf> [dostęp: 6.11.2016]. 
Drugą z sytuacji typu mise en abyme kreuje cyrkularność, samozwrotność czy samoodniesienie - relacja obiektu względem samego siebie - co prezentujemy poniżej w wydaniu wizualnego paradoksu autorstwa Mauritsa C. Eschera (litografia z 1948 roku) pt. Rysujace sie ręce oraz w jednej z prezentacji tzw. Ouroboros, tj. symbolicznego węża połykającego własny ogon, tu w skojarzeniu z symbolem nieskończoności. Oprócz związanego z paradoksem akcentu epistemologicznego, zauważyć tu warto także pewien ładunek przewrotnego humoru.

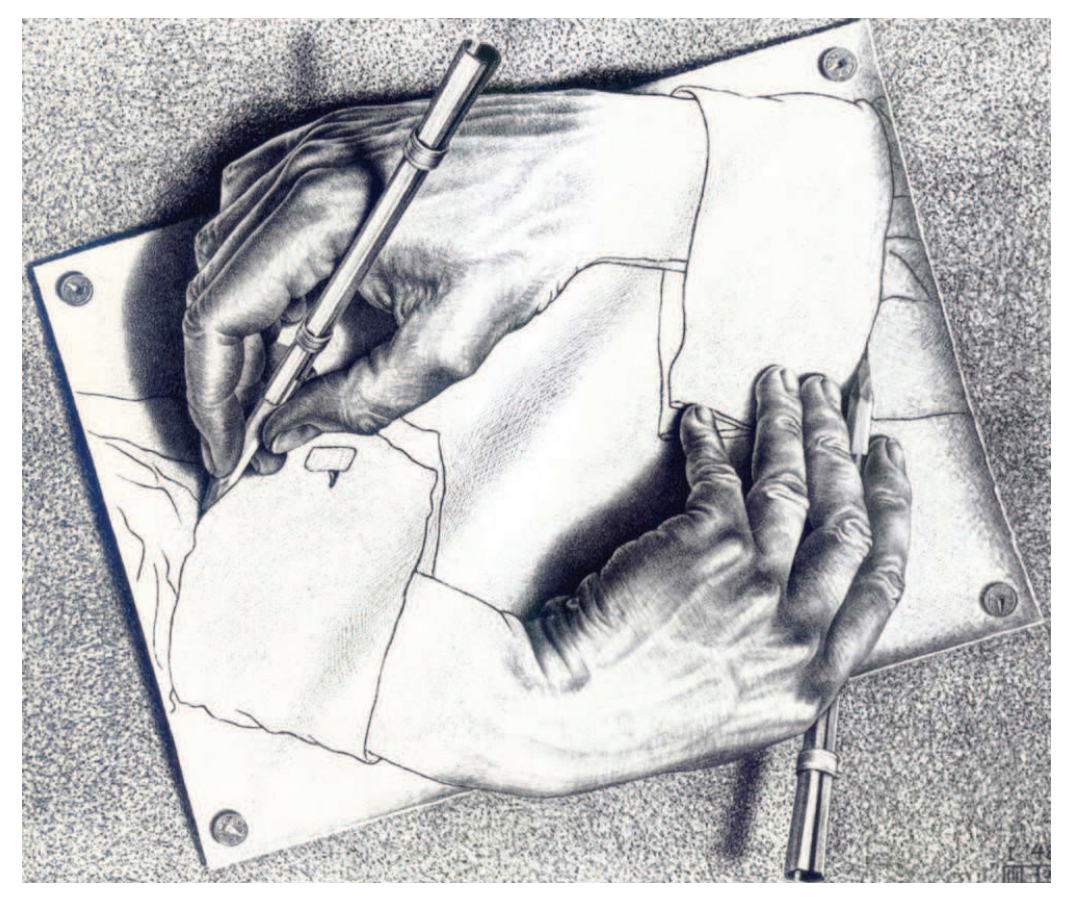

Ilustracja 3.

Maurits C. Eschera (1948 r.), Rysujqce się ręce,

$<$ https://en.wikipedia.org/wiki/Drawing_Hands>. 


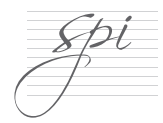

Ilustracja 4.

Ouroboros. Symbol nieskończoności, $<$ http://mythologian.net/ouroboros-symbol-of-infinity/>.

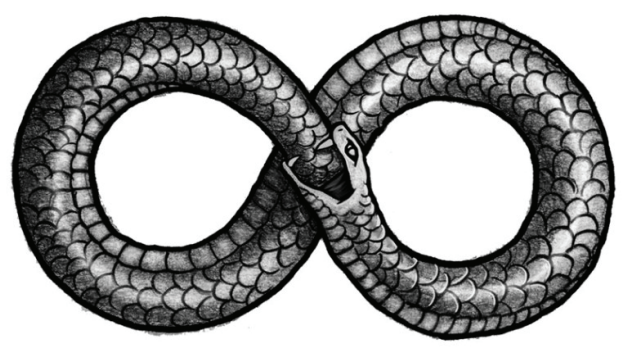

Trzecią wreszcie sytuację typu mise en abyme odnajdujemy w "grze” dwóch naprzeciwległych i równoległych luster, prezentowanej poniżej w kadrze z Obyrwatela Kane'a, kultowego filmu sprzed 75 lat, który wyreżyserował i w którego tytułowej roli Charlesa Kane'a wystąpił amerykański twórca filmowy Orson Welles. To sytuacja wskazująca na nieskończoność zwierciadlanych odbić i na redukcję ad absurdum.

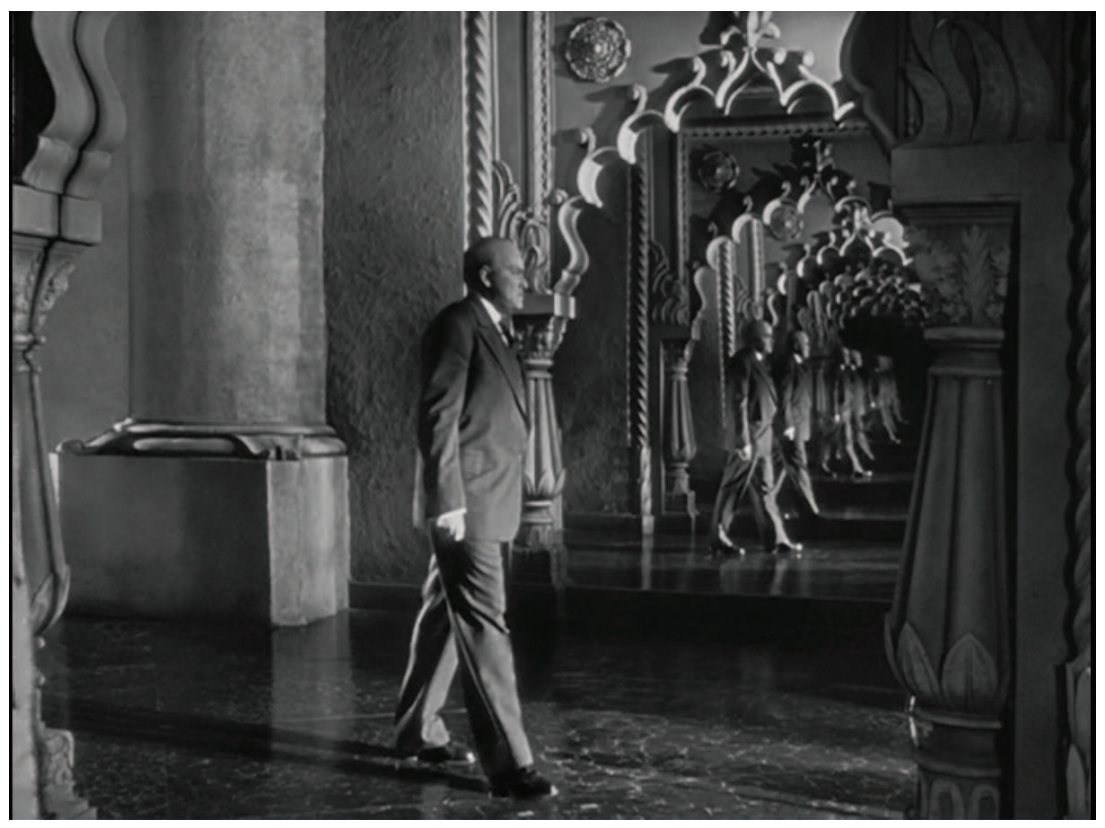

Ilustracja 5.

Kadr z filmu Obywatel Kane (1941 r.), <http://lyoung101.qwriting.qc.cuny.edu/2011/09/23/citizen-kane-orson-wellesusa1941/>. 


\section{Edukacja domowa - \\ niejednoznaczność i ambiwalencja prawnych regulacji}

Właśnie ta ostatnia sytuacja, choć w rzeczywistości zawsze skażona jest wzajemnie pogłębiającymi się nieuniknionymi deformacjami obrazu, służy w tym miejscu za metaforę aktualnej kondycji polskiej edukacji domowej, kondycji rozumianej jako kompleks uwarunkowań, którym dany „obiekt” podlega.

Zanim jednak pojawią się opisy tejże kondycji, konieczne wydaje się przedstawienie stosownej, choć zaledwie ogólnej definicji edukacji domowej. Tu proponuje się następującą, własną definicję:

Edukacja domowa to względnie legalna, społecznie odmienna od szkolnej i wyłącznie w obrębie rodziny realizowana organizacyjn a forma kształcenia się dzieci i młodzieży, będących w wieku jednego $z$ obowiązków edukacyjnych, i obłożona pewnymi warunkami, lub też legalna, alternatywna, nieuwarunkowana, kompleksowa, familijna opcja edukacyjna.

Jak widać, zachodzą dla tej szczególnej organizacyjnej, a więc społecznej formy kształcenia zasadniczo dwie możliwości realizacyjne: w pierwszej rodzina jest zależna od państwowego systemu oświatowego i przezeń warunkowana, w drugiej jest odeń niezależna, aczkolwiek legalna, prawem regulowana. Wyróżnione w powyższej definicji cechy gatunkowe dla omawianego edukacyjnego fenomenu zostaną omówione poniżej.

Wspomnijmy jeszcze nawiasem, że edukacja domowa wyrasta stopniowo, szczególnie w USA, choć także i w Polsce, przewyższając w tym zakresie nawet popularne sieci szkolne (np. szkół montessoriańskich), na główną alternatywę dla państwowej oferty oświatowej w dzisiejszym świecie ${ }^{3}$.

Generalnym problemem dla edukatorów domowych jest jedynie „niefundamentalna” i specyficzna legalność czy prawowitość domowego nauczania, i to $\mathrm{w}$ dwóch rozumieniach. Po pierwsze, przepisy prawa jej dotyczące (podobnie zresztą jak wszystkie pozostałe przepisy prawa) mogą zostać w każdym czasie, wszelako jednak zawsze „nieostatecznie”, przez kolejnego ustawodawcę zmienione, brak zatem

3 Zob, np. B.D. Ray, Research facts on homeschooling, 2016, <https://www.nheri. org/research/research-facts-on-homeschooling.html> [dostęp: 6.11.2016]. 
u rodziców edukację domową realizujących poczucia stabilności, która to stabilność jest warunkiem konsekwentnej realizacji obranej strategii edukacyjnego postępowania, po wtóre zaś, najczęściej nakładają owe przepisy na korzystających z tego uprawnienia rodziców różnego rodzaju i różne co do stopnia uciążliwości warunki, które bywają sprzeczne z podstawowymi rozstrzygnięciami prawa krajowego.

Niezależnie od labilności prawa (rzeczywiście często u nas, w kraju, ,modyfikowanego”) i generalnego braku gwarancji dla niezakłóconego uprawiania edukacji domowej, najistotniejszą jest dla edukatorów domowych właśnie obecność i, ewentualnie, jakość warunków na nich nakładanych.

Może być tak, jak to ma miejsce w licznych anglosaskich regulacjach prawnych (np. w Anglii czy w około 30 stanach USA), że rodzice mają pełną możliwość decydowania o kształcie „ogólnokształcącej” edukacji własnych dzieci. I to w każdym wymiarze: tak co do programu wychowawczego, jak i treści, instrumentarium oraz metod dydaktycznych w odniesieniu do pozyskiwania wiedzy i umiejętności kulturowych. Jeśli „absolwent” takiej „nieuregulowanej" rodzicielskiej edukacji domowej chciałby przejść kurs edukacji zawodowej, to robi to zgodnie $\mathrm{z}$ wymaganiami branżowymi, a gdyby chciał studiować w uczelni wyższej, to może (za naprawdę niewielką opłatą) $)^{5}$ zdać jeden ze standaryzowanych egzaminów, wymaganych przez daną uczelnię. Wszelako bez przymusu! Są to zatem rozwiązania, które honorują autonomię pełnoletnich młodych ludzi, podlegających jeszcze obowiązkowi edukacji, a co do młodszych dzieci całkowitą odpowiedzialność oddają w ręce ich rodziców lub prawnych opiekunów. I to niezależnie od ich formalnych kompetencji kształceniowych, a nawet poziomu ich własnego wykształcenia! Dzieje się tak właśnie dlatego, że rodzice są z natury (a dla wierzących: z poruczenia Boga) pierwszymi wychowawcami i nauczycielami własnych dzieci ${ }^{6}$.

4 Patrz odpowiednio: <https://www.hslda.org/hs/international/UnitedKingdom/ default.asp> oraz <https://www.hslda.org/laws/default.asp> [dostęp: 6.11.2016].

5 Dla najczęściej zdawanych w USA testów o charakterze „matury” (SAT i ACT) to koszt rzędu 60 USD.

6 Zob. np. <https://www.hslda.org/laws/default.asp> [dostęp: 6.11.2016]. 
Skądinąd poczyńmy tę istotną tu dygresję: wszystkie główne międzynarodowe konwencje praw człowieka na ów priorytet rodziców w tym względzie jednoznacznie wskazują ${ }^{7}$.

Zacytujmy dla przykładu w tym odniesieniu Kartę Praw Podstawowych Unii Europejskiej (choć podobne regulacje zawarto także w Powszechnej Deklaracji Praw Człowieka, dwóch międzynarodowych Paktach Praw z 1966 roku czy w Konwencji o Prawach Dziecka) $)^{8}$, obowiązującą także państwo polskie. W jej art. 14, ust. 3, stwierdza się, że:

Wolność tworzenia placówek edukacyjnych z właściwym poszanowaniem zasad demokratycznych i prawo rodziców do zapewnienia wychowania i nauczania dzieci zgodnie $\mathrm{z}$ własnymi przekonaniami religijnymi, filozoficznymi i pedagogicznymi są szanowane, zgodnie z ustawami krajowymi regulującymi korzystanie z tej wolności i tego prawa?.

To pierwsza z międzynarodowych konwencji, która obok poglądów religijnych i filozoficznych na pierwszym edukacyjnie miejscu stawia także przekonania pedagogiczne rodziców, choć niestety dalej $\mathrm{w}$ tym samym przepisie czyni możność korzystania $\mathrm{z}$ tego prawa zależnym od regulacji państwa członkowskiego. Trudno to rozwiązanie uznać za logicznie konsekwentne, co w praktyce przejawia się w legislacjach takich krajów, jak Niemcy czy Szwecja, które edukacji domowej zabraniają, a opornych karzą. Takie to „europejskie" poszanowanie woli rodziców!

Dodajmy także, że Misja Stałego Obserwatora Stolicy Apostolskiej przy ONZ na 45. nowojorskiej sesji Komisji Populacji i Rozwoju (24.04.2012) przedłożyła ONZ jednoznaczne stanowisko w obronie edukacyjnej wolności rodziców, stwierdzając:

Katolickie szkoły wspierają rodziców, którzy mają prawo i obowiązek wyboru szkół, włącznie z homeschoolingiem, i muszą posiadać swobodę czynienia tego, która to wolność z kolei musi być respektowana i uprzystępniana przez państwo ${ }^{10}$.

7 Multilateral Treaties Deposited With The Secretary-General, 2017, <https://treaties.un.org/doc/source/titles/english.pdf> [dostęp: 6.11.2016].

8 Tamże.

9 Zob. Karta praw podstawowych Unii Europejskiej,2012, <http://eur-lex.europa. eu/legal-content/PL/TXT/PDF/?uri=CELEX:12012P/TXT\&from=PL> [dostęp: 6.11.2016].

10 Statement by the Holy See Delegation before the 45th session of the Commission on Population and Development of the United Nations Economic and Social 
Stanowisko to, niestety, nie jest tymczasem wspierane wobec władz krajowych przez narodowe episkopaty, w tym także nie czyni tego Konferencja Episkopatu Polski ${ }^{11}$.

\section{Edukacja domowa w Polsce - „Żyzne pole pełne chwastów”}

W Polsce brak jest jednak nie tylko pełnej, ale nawet znaczniejszej co do zakresu rodzicielskiej swobody edukacyjnej względem edukacji domowej. Rodzice muszą tu:

1) wnioskować o zezwolenie na domową edukację własnego dziecka (i to dla każdego $\mathrm{z}$ własnych dzieci z osobna) do dyrektora wybranej szkoły, która to czynność administracyjna ma dla tego ostatniego charakter czysto uznaniowy i, w wypadku odmowy, nie podlega zaskarżeniu. Skądinąd kurator, jako organ wyższego stopnia, może jedynie zwrócić sprawę „do ponownego rozpatrzenia” przez tegoż dyrektora. Jednak, co istotniejsze, rozwiązanie to przede wszystkim sprzeciwia się rodzicielskiemu decyzyjnemu priorytetowi co do edukacji własnych dzieci, gwałcąc owo, wyżej wspomniane uprawnienie, bezpardonowo. Co więcej, sprawę komplikują logicznie splątane zapisy art. 70 Konstytucji RP, stanowiąc najpierw o obowiązku nauki (która może być przecież realizowana w różnych miejscach), a dalej delegując na ustawę przedmiotową, tu oświatową, możność określenia „sposobu wykonywania obowiązku szkolnego"12. Wreszcie, dodajmy, warunek ten ma znamiona dyskryminacji, ponieważ pozostali polscy rodzice nie muszą wnioskować do dyrektora szkoły o zezwolenie na edukację w niej własnego dziecka, obejmowanego przez jeden z obowiązków edukacyjnych (tu krajowych prawodawców, a raczej urzędników sugerujących im takie rozwiązania, trzeba uznać za światowych rekordzistów w kreowaniu kolejnych odmian obowiązku edukacyjnego, których wygenerowano aż trzy - sic! $)^{13}$;

Council, New York, 24 April 2012, <https://holyseemission.org/contents// statements/55e34d3655b117.95953634.php> [dostęp: 8.11.2016].

11 Jedyny akt względem edukacji domowej ze strony hierarchów polskiego Kościoła Katolickiego to Komunikat Komisji Wychowania Katolickiego Konferencji Episkopatu Polski w sprawie nauczania religii w pozaszkolnym systemie edukacji domowej (28.06.2016). Zob. <http://www.katecheza.episkopat.pl/> [dostęp: 8.11.2016].

12 Art. 70, ust. 1 Konstytucji RP.

13 Art. 16, ust. 8 i nn. Ustawy o systemie oświaty. 
2) muszą poddawać się żądaniom dyrektora szkoły, których prawo nijak nie limituje ${ }^{14}$, a które w praktyce przeczą innym zapisom ustawy oświatowej (np. niektórzy dyrektorzy żądają, by dziecko poddawało się egzaminom klasyfikacyjnym dwa razy do roku albo kolejnym sprawdzianom wiedzy i umiejętności, ustawowo wykluczonym);

3) muszą poddawać swoje dzieci, a niekiedy nawet poddawać się sami (zdarzały się takie roszczenia dyrektorów szkół i dyrektorów publicznych poradni psychologiczno-pedagogicznych!) badaniom w poradniach psychologiczno-pedagogicznych, a ich wyniki muszą przedłożyć $\mathrm{w}$ dokumentacji towarzyszącej przedmiotowemu wnioskowi, podczas kiedy wszyscy pozostali polscy rodzice udają się ze swymi dziećmi do poradni psychologiczno-pedagogicznych dobrowolnie, a wyniki badań w nich przeprowadzonych mogą zastrzec do prywatnego wylącznie użytku ${ }^{15}$. Dodajmy, że regulacje dotyczące działania poradni psychologiczno-pedagogicznych w żaden sposób nie określają trybu postępowania w przypadku życzenia sobie przez rodziców edukacji domowej dla swojego dziecka, bo poradnie zajmują się wyłącznie „problemami” dzieci, zaś edukacja domowa w ogóle nie ma takiego charakteru. Co gorsza, doradcy uzurpują sobie niekiedy prawo do decydowania o tym, czy danemu dziecku ma przysługiwać edukacja domowa, czy też nie;

4) muszą zobowiązywać się do realizacji państwowej podstawy programowej, nawet gdyby niektóre jej treści były dla nich moralnie i światopoglądowo nieakceptowalne, co godzi w obywatelskie prawo do posiadania wybranych przez siebie poglądów i przekonań, w tym przekonań określonej grupy kulturowej (także wspólnoty religijnej);

5) muszą wreszcie „dostarczać” swoje dzieci na roczne egzaminy klasyfikacyjne, opiewające na całoroczne treści programowe, które to egzaminy, poza dziećmi edukacji domowej, są obligowani zdawać jedynie szkolni „przestępcy”, tj. notoryczni i długotrwali wagarowicze ${ }^{16}$. Mętne jest też uregulowanie dotyczące ewentualnego

14 Art. 18, ust. 3 Ustawy o systemie oświaty.

15 Rozporządzenie MEN w sprawie szczegółowych zasad działania publicznych poradni psychologiczno-pedagogicznych, w tym publicznych poradni specjalistycznych, §5, ust. 1 i 13 .

16 W języku formalnym wyrażone są wskazane w tekście treści w Ustawie o systemie oświaty i Rozporządzeniu MEN w sprawie szczegółowych zasad działania publicznych poradni psychologiczno-pedagogicznych. 
egzaminu poprawkowego, zasadniczo bowiem z przepisu ustawowego wynika brak takiej możliwości dla „uczniów” edukacji domowej, a więc jest to kolejna zalegalizowana dyskryminacja ${ }^{17}$.

Cóż, powiedzieliby niektórzy, dura lex, sed lex. Państwo ma i musi mieć przecież prawo do nieufności wobec obywateli, szczególnie tak bardzo niepokornych.

Jednak nieufność funkcjonariuszy państwa wobec rodziców (skądinąd, na jakiej podstawie ich urzędniczych działań owa aprioryczna nieufność się nie ima, choć też są tego samego państwa obywatelami i, bodaj, od pozostałych obywateli niczym się nie różnią) nie tylko gwałci konstytucyjną - choć wynikającą zaledwie z tekstu preambuły, a nie właściwych przepisów Konstytucji - zasadę pomocniczości państwa, wedle której tam, gdzie obywatel samodzielnie sobie radzi, interwencja czynników państwa jest zbędna, a przede wszystkim nie znajduje wiarygodnego uzasadnienia dla wprowadzanych i wymuszanych prawem rozwiązań. ${ }^{18}$

Część fundamentalnych rozwiązań oświatowych, poprzez swoje prawne niedookreślenie lub ewidentne wady, generuje w powszedniej praktyce oświatowej edukacyjne i moralne „efekty-defekty”, tak jak dla mise en abyméowego układu luster ich wady powodują nieadekwatne, zdeformowane „odbicia”.

Polski państwowy system oświaty w części stworzył, a w części mechanicznie od dziewiętnastowiecznych Prusaków skopiował i konsekwentnie polityczną mocą kultywuje (a na szkołach niepublicznych wymusza) funkcjonalne zasady: standaryzacji, heteronomii zadań, obiektywnej, niby-kryterialnej ewaluacji, stymulowania rywalizacji o status w grupie, zewnętrznego motywowania i zarządzania przez lęk.

Edukacja domowa ze swej strony, bez odwoływania się do państwowego uzusu i potwierdzających go niekiedy konstatacji formalnie naukowych z dziedziny pedagogiki, a szczególnie dydaktyki, na bazie powszednich doświadczeń pozwala na wglądy odzwierciedlające zupełnie odmienne oblicze i potrzeby dziecka (jego naturalną kondycję), które winny być respektowane poprzez wdrażanie do edukacyjnej praktyki zasad: indywidualizacji, a nawet częściowej personalizacji (tu

17 Zob. preambuła do Konstytucji RP, <http://www.sejm.gov.pl/prawo/konst/ polski/kon1.htm> [dostęp: 8.11.2016].

18 Tamże. 
rozumianej jako pozwalanie dziecku na samodzielne dokonywanie edukacyjnych wyborów), a w konsekwencji autonomizacji, intrapersonalnej ewaluacji (bez porównań z innymi uczniami i z dopuszczaniem możliwości popełniania błędów), dezegoizacji, altruizmu i współpracy, wreszcie sprzyjania wewnętrznej motywacji z wyłączaniem lęku przed karą i pragnienia dominowania nad innymi.

Jednocześnie edukacja domowa to pole doświadczeń zmuszających do pokory, ujawniających nasze ludzkie, sytuacyjne niedoskonałości poznawcze, emocjonalne, wolicjonalne, zdrowotne i funkcjonalne nie tylko po stronie dziecka, ale także po stronie edukatorów-rodziców (do których to chwil słabości nauczyciele szkolni, ich przełożeni i urzędnicy nadzoru oświatowego najczęściej nie są zdolni się przyznawać ani za które nie raczą, w przypadku szkód, przepraszać).

System oświatowy, być może z powodu pierwotnej swej skazy, politycznego "grzechu pierworodnego" - nota bene, właśnie celebrowano Dzień Edukacji Narodowej jako pamiątkę po ideologicznie nieoczywistej przecież Komisji Edukacji Narodowej, której powstanie dokładnie 33 lata poprzedziło niesławną klęskę wojsk pruskich z napoleońskimi pod Jeną i Auerstedt, a która to klęska była bezpośrednią przyczyną wprowadzenia owego pierwszego w świecie powszechnego „obowiązku szkolnego" w królewskich Prusach, co stało się wyłącznie z uwagi na polityczną żądzę ich króla Fryderyka Wilhelma III do panowania nad duszami swych poddanych - w zdeformowany sposób odbija kondycję ludzkich dzieci, a władze oświatowe naszego państwa (szczególnie ich centrum ministerialne) nie dopuszczają potrzebnych (i jak pokazuje pozytywny przykład Finlandii - możliwych) zmian, które trafniej odzwierciedlałyby ludzką kondycję „edukacyjną” małych i nastoletnich Polaków, jaką ze swej strony dokumentują doniesienia z bezpośrednich doświadczeń polskich edukatorów domowych ${ }^{19}$.

MEN od 1989 roku, od roku zmian ustrojowych (był też okres, w którym działał pod skrótem MENiS), prowadzi grę, w której przez wielokrotne, biurokratyczne i deformujące „odbicia” naturalnej kondycji dziecka wciągają edukację domową, a ściślej rodziny edukacji domowej w abyme, abisal czy otchłań pragmatycznego absurdu oraz, niestety, w otchłań moralną (otchłani metafizycznej w tym kontekście

19 Zob. liczne już polskie blogi poświęcone edukacji domowej. 


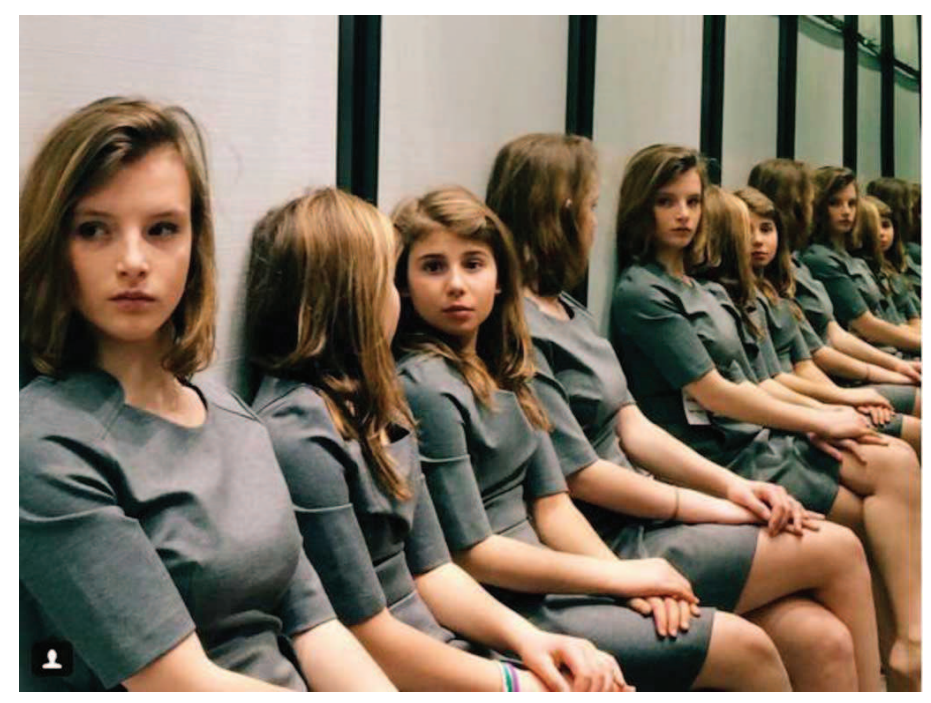

Ilustracja 6.

T. Vergari, Same but different (2017), <https://www.swiatobrazu.pl/zdjecie-zagadka-33234.html>.

Ilustracia 7. Mali Einsteini: Krzywe lustra, http://www.zacisze.waw.pl/pl/artykul/2903.

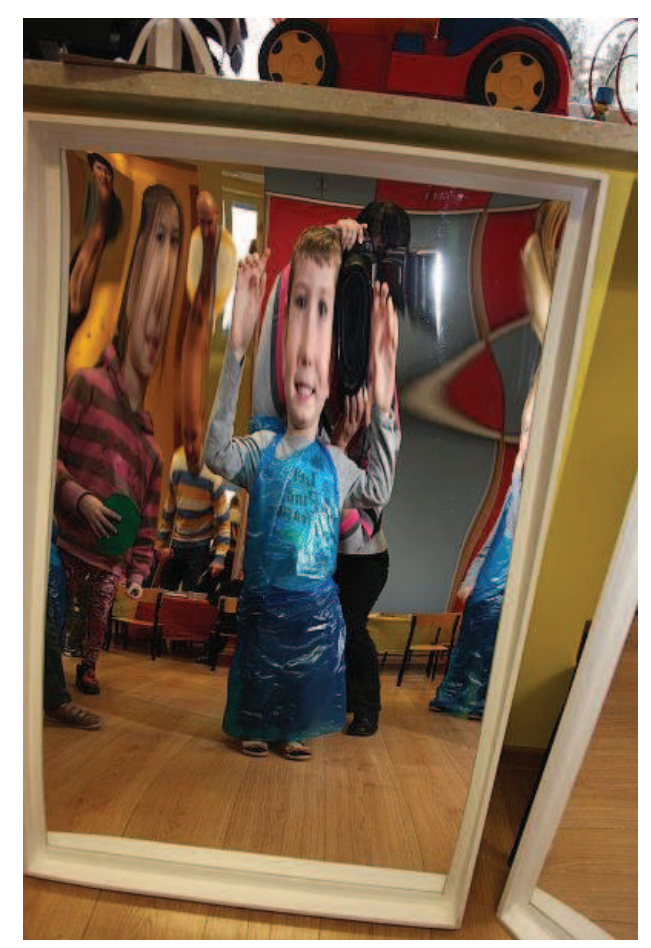


nie wspominam $)^{20}$. Na tym właśnie polega tytułowe skojarzenie mise en abyme $\mathrm{z}$ polską edukacją domową.

Stąd wydaje się, że poniższe „zwierciadlane” wizerunki oddają symbolicznie kondycję polskiej edukacji domowej.$$
* * *
$$

A przecież tak niewiele trzeba, by odbicie prawdziwej istoty konkretnego dziecka stało się względnie adekwatne. Edukacja domowa, między innymi, bo nie tylko ona, wskazuje właściwy w tym odniesieniu kierunek, ponieważ jest wobec naturalnej kondycji dziecka, a zatem i względem świata innych ludzi i zamieszkiwanej przez nas planety, zasadniczo odpowiedzialna. Państwowy system oświaty mógłby w swych rozwiązaniach, gdyby spożytkowano w nich doświadczenia polskiej edukacji domowej, także na tych doświadczeniach skorzystać. Przede wszystkim zaś prawodawcy prawa oświatowego winni edukacji domowej sprzyjać, eliminując wszelkie prokurowane i przypadkowe dla niej obstrukcje.
\end{abstract}

\title{
Bibliografia
}

Budajczak M. Edukacja domowa, Gdańskie Wydawnictwo Psychologiczne, Gdańsk 2004.

Dällenbach L., Le récit spéculaire. Essai sur la mise en abyme, Seuil, Paris 1977. Konstytucja Rzeczypospolitej Polskiej (Dz.U. 1997, nr 78, poz. 483).

Rozporządzenie MEN w sprawie szczegółowych zasad działania publicznych poradni psychologiczno-pedagogicznych (Dz.U. 2013, poz. 199).

Ustawa o systemie oświaty (Dz.U. 1991, nr 95, poz. 425).

\section{$\mathrm{Ne}$ tografia}

Gitizen Kane (Orson Welles/USA/1941), <http://young101.qwriting.qc.cuny. edu/2011/09/23/citizen-kane-orson-wellesusa1941/> [dostęp: 20.06.2017].

Drawing Hands, <https://en.wikipedia.org/wiki/Drawing_Hands> [dostęp: 20.06.2017].

Eschera M.C. (1948 r.), Rysujące się ręce, <https://en.wikipedia.org/wiki/ Drawing_Hands> [dostęp: 20.06.2017].

20 Wadliwe i obstrukcyjne przepisy „demoralizują” niektórych edukatorów domowych, skłaniając ich do omijania tychże przepisów i przyciągają spekulantów oświatowych, korzystających materialnie na edukacji domowej. 
Giotto di Bondone (ok. 1320 r.), Tryptyk Stefaneschiego, Muzeum Watykańskie, <http://www.museivaticani.va/content/museivaticani/en/colle zioni/musei/la-pinacoteca/sala-ii---secolo-xiii-xv/giotto-di-bondone-e-aiuti--trittico-stefaneschi.html> [dostęp: 20.06.2017].

Karta praw podstawowych Unii Europejskiej, 2012, <http://eur-lex.europa.eu/ legal-content/PL/TXT/PDF/?uri=CELEX:12012P/TXT\&from=PL > [dostęp: 20.06.2017].

Komunikat Komisji Wychowania Katolickiego Konferencji Episkopatu Polski w sprawie nauczania religii w pozaszkolnym systemie edukacji domowej (28.06.2016), <http://www.katecheza.episkopat.pl/> [dostęp:20.06.2017].

Konstytucja Rzeczypospolitej Polskiej, <http://www.sejm.gov.pl/prawo/konst/ polski/kon1.htm> [dostęp: 20.06.2017].

Mali Einsteini: Krzywe lustra, <http://www.zacisze.waw.pl/pl/artykul/2903> [dostęp: 20.06.2017].

Multilateral Treaties Deposited With The Secretary-General, 2017, <https://trea ties.un.org/doc/source/titles/english.pdf> [dostęp: 20.06.2017].

Ouroboros. Symbol nieskończoności, <http://mythologian.net/ouroboros-sym bol-of-infinity/> [dostęp: 20.06.2017].

Pudetko kakao firmy Droste (ok. 1920 r.), <https://en.wikipedia.org/wiki/ Droste_effect>, [dostęp: 20.06.2017].

Ray B.D., Research facts on homeschooling, 2016, <https://www.nheri.org/ research/research-facts-on-homeschooling.html> [dostęp: 20.06.2017].

Statement by the Holy See Delegation before the 45th session of the Commission on Population and Development of the United Nations Economic and Social Council, New York, 24 April 2012, <https://holyseemission.org/contents// statements/55e34d3655b117.95953634.php> [dostęp: 20.06.2017].

Vergari T., Same but different (2017), <https://www.swiatobrazu.pl/zdjecie -zagadka-33234.html> [dostęp: 20.06.2017].

https://web.archive.org/web/20131102033517/http://www.courtauld. ac.uk/researchforum/projects/medievalarttheory/documents/Mise-en -abyme.pdf [dostęp: 20.06.2017].

https://www.hslda.org/hs/international/UnitedKingdom/default.asp [dostęp: 20.06.2017].

https://www.hslda.org/laws/default.asp [dostęp: 20.06.2017].

\section{ADRES DO KORESPONDENCJ:}

Dr hab. Marek Budajczak, prof. UAM

Uniwersyłet im. Adama Mickiewicza w Poznaniu

Wydział Studiów Edukacyinych

Zakład Poradnictwa Społecznego

e-mail: putaiszy@amu.edu.pl 